\title{
留 \\ UMAT BERAGAMA \\ SEBAGAI MASYARAKAT BERADAB: IDENTITAS AGAMA VS KEBANGSAAN
}

\author{
Anwar Mujahidin \\ STAIN Ponorogo \\ pranotogomo@yahoo.com
}

\begin{abstract}
Abstrak
Agama bisa menjadi penghambat bahkan musuh masyarakat sipil, apabila ia menawarkan nilai-nilai yang eksklusif dan mengedepankan kebenaran yang tunggal. Untuk itu, semangat pluralisme menjadi sangat penting bagi suatu bangsa yang rakyatnya berbeda agama. Pluralisme ini tidak sekadar saling mengakui kebenaran agama lain untuk menjaga kerukunan antar umat beragama, tetapi menjadi sumber nilai bersama (consensus) yang menjadi identitas kewarganegaraan. Nilai-nilai agama yang hendak dijadikan acuan masyarakat sipil harus diobyetifikasi sehingga nilai itu tidak hanya bermakna bagi kelompoknya tetapi juga kelompok-kelompok lain sesama warga bangsa. Dalam konteks ini keberadaan Pancasila patut direvitalisasi dan dikembalikan pada sejarah awalnya sebagai konsensus bersama bangsa Indonesia.
\end{abstract}

\begin{abstract}
Religion can be a barrier, even enemy of civilians, when it offers exclusive values and promote a single truth. To that end, the spirit of pluralism becomes very important for a nation where its people differ in religion. Pluralism is not merely mutual recognition of the truth of other religions to maintain inter-religious harmony, but it also a source of shared values (consensus) which become civic identity. Religious values to be used as a reference for civil society have to be objectified so that the value is not only significant for a group but also for other groups of fellow citizens. In this context, the existence of Pancasila should be revitalized and restored in its early history as a mutual consensus of Indonesian nation.
\end{abstract}

Kata Kunci: Masyarakat sipil, identitas kewarganegaraan, pluralisme. 


\section{A. Pendahuluan}

Demokrasi merupakan jawaban terhadap sistem politik yang menindas dan memihak kelompok kepentingan tertentu di samping sejumlah nilai yang perlu ditegakkan oleh masyarakat sehingga tercipta hubungan sosial politik yang sehat. Di tengah carut marut pertengkaran elit dan ketidak percayaan rakyat, demokrasi menjanjikan penegakan hukum, hak asasi rakyat untuk mendapat informasi yang benar, ikut menemukan identitas kolektif baik lewat pemilu yang adil maupun lewat kontrol sosial, serta berpartisipasi dalam bernegara dan pendayagunaan saranasarana eksistensi yaitu pengaturan ekonomi dan sosial. ${ }^{1}$

Namun bangsa Indonesia dan orang yang memimpikan demokrasi untuk menghasilkan harapan yang demikian besar tentu telah kecewa. Demokrasi harus lahir dengan kekerasan dan konflik yang berkepanjangan, namun pemerataan pertumbuhan ekonomi yang dapat dirasakan oleh rakyat kebanyakan tidak juga menampakkan hasilnya, bahkan pengangguran semakin merajalela; tiadanya rasa aman karena kriminalitas semakin meluas dan nekat; korupsi tidak juga mereda; angka kemiskinan semakin tinggi. Kelompok yang lemah tetap akan tersingkir.

Carut marut di atas menjadi semakin rumit dalam era globalisasi sekarang ini, di mana penentu dari stabilitas dan kebijakan negara bukanlah pemegang kekuasaan yang diberi mandat oleh rakyat semata, tetapi juga dunia internasional, yaitu negara-negara maju dan para pe-megang modal internasional. Menurut pengamatan sosiolog asal Inggris Anthony Gidden, terancamnya demokrasi dan otoritas sipil sebagai akibat tarikmenarik antara kekuatan negara dan pasar. Arah politik saat ini menurut Gidden memang sedang terombang-ambing antara arus kiri yang menghendaki nilai dan arus kanan yang menghendaki kebebasan pasar. ${ }^{2}$ Indonesia kini juga sangat jelas berada dalam arus gelombang besar antara kekiri atau kekanan. Tuntutan untuk mengikuti kapitalisme internasional, tunduk kepada para investor

${ }^{1}$ Francis Wahono, "Bersekongkol atau Saling Kontrol", dalam Duto Sosialismanto, Hegemoni Negara, Ekonomi, Politik Pedesaan Jawa, (Yogyakarta: Lapera Pustaka Utama, 2000), h. xxxv.

${ }^{2}$ Anthony Giddens, The Third Way And Its Critics, diterjemahkan oleh: Imam Khoiri, (Yogyakarta: IRCiSoD, 2000), h. 45. 
asing, pasar bebas sangat nampak pada desakan untuk mencabut subsidi pemerintah terhadap kebutuhan pokok seperti BBM dan desakan untuk melepas saham-saham pemerintah di BUMN dengan alasan penyehatan. Bagaimana hubungan negara, pasar dan masyarakat ini harus di atur?

Dalam arus globalisasi tidak ada pusat kekuasaan yang pasti, batas yang pasti, sehingga juga tidak ada bentuk ideal yang pasti antara hubungan negara, pasar dan masyarakat, semuanya dalam pertarungan atau lebih halusnya adalah negosiasi. Dalam proses negosiasi ini, negara diwakili oleh pelaku politik, pasar diwakili oleh para kapitalis atau pemodal besar. Pertanyaannya adalah siapa yang mewakili masyarakat?

Dalam situasi negosiasi inilah, masyarakat sipil digagas untuk mewakili dan memperjuangkan nilai, kebebasan, dan isuisu lainnya yang diabaikan akibat kemenangan kapitalis dan negara. Menurut Giddens, posisi dan kedudukan pemerintah, pasar dan masyarakat harus seimbang. Kekhawatiran politik kanan (neoliberal) bisa dibenarkan karena negara bisa menjadi terlalu besar dan terlalu kuat, namun jika negara terlalu dibatasi atau kehilangan legitimasinya, akan muncul persoalan-persoalan sosial besar. Begitu juga bila kondisi masyarakat sipil terlalu lemah, maka pemerintah yang efektif dan pertumbuhan ekonomi juga akan menghadapi resiko. ${ }^{3}$

Terwujudnya masyarakat sipil yang berdaya di hadapan struktur negara dan pasar yang kuat sudah tidak bisa ditundatunda lagi, namun cita-cita ini banyak mengalami kendala. Struktur sosial masyarakat Indonesia yang majmuk membuat masyarakat sulit terintegrasi dalam satu kehendak bersama (common will) sehingga di dalam masyarakat sendiri terjadi potensi perpecahan. Dalam struktur masyarakat yang plural tersebut menurut Pierre L. Van den Berghe terbuka peluang adanya konflik antar kelompok masyarakat sendiri sehingga integrasi yang terjadi lebih karena adanya paksaan (coercion) dan melahirkan dominasi politik oleh suatu kelompok atas kelompok-kelompok yang lain. ${ }^{4}$

${ }^{3}$ Ibid., h. 57.

${ }^{4}$ Nasikun, Sistem Sosial Indonesia, (Jakarta: Raja Grafindo Persada, 1995),

h. 33 . 
Segmentasi dalam bentuk terjadinya kesatuan-kesatuan sosial yang terikat ke dalam oleh ikatan-ikatan primordial mudah sekali menimbulkan konflik-konflik di antara yang paling mendasar adalah munculnya sikap fundamentalisme dalam beragama sehingga menghambat warga masyarakat untuk menemukan identitasnya sebagai warga bangsa. Gerakan fundamentalis di Indonesia mengejawantah dari kelompok yang paling ekstrim yang menghendaki negara Islam sampai yang ingin menerapkan syariat Islam. Sebagaimana dinyatakan oleh Haryatmoko, dalam masyarakat yang plural seperti Indonesia, tuntutan teokrasi berlawanan dengan konsep bangsa. Konsep bangsa mengandaikan, 1) Adanya acuan kebudayaan yang sama, dalam arti suatu sistem gagasan, tanda, dan cara bertindak dan berkomunikasi. Tuntutan ini tidak mungkin dipenuhi kalau bangsa yang menjadi alat legitimasi hanya dikuasai oleh kalangan elite terbatas dan budaya yang menjadi dasar kekuasaan merupakan milik kelompok tertentu. 2) Bangsa merupakan bangunan keyakinan, loyalitas, dan solidaritas anggota-anggotanya. Bila legitimasi kekuasaan berdasar atas agama tertentu sebagian masyarakat lain sudah dengan sendirinya dinafikan. 3) Bangsa terbentuk bila anggota-anggota masyarakat saling mengakui hak-hak dan kewajiban-kewajiban masing-masing karena status mereka sama. Tuntutan ini tidak mungkin dipenuhi dalam negara teokrasi karena pemeluk agamaagama lain praktis tidak mempunyai hak dan kewajiban yang sama alias menjadi warga negara kelas dua. ${ }^{5}$

\section{B. Fokus Masalah}

Makalah ini akan mengurai masalah fundamental dalam pembentukan masyarakat sipil di Indonesia yaitu kesadaran bersama sebagai warga bangsa yang belum sepenuhnya terwujud, karena masyarakat banyak yang masih terkurung dalam kesadaran primordialnya sebagai ummat atau pemeluk suatu agama yang berbeda dengan pemeluk agama lain. Agama menjadi idiologi dan identitas diri yang lebih menonjol ketimbang identitas sebagai warga negara, sehingga berpotensi melahirkan masalah baru di

${ }^{5}$ Haryatmoko, Etika Politik dan Kekuasaan, (Jakarta: Penerbit Buku Kompas, 2003), h. 200-201. 
luar masalah yang seharusnya diperjuangkan yaitu perwujudan nilai-nilai sipil di hadapan negara dan pasar. Bagaimana seharusnya umat sebagai pemeluk suatu agama memahami agamanya sehingga agama justru menjadi sumber nilai bersama warga bangsa yang plural dan bagaimana kelompok atau oraganisasi keagamaan tidak hanya memperjuangkan isu-isu primordial yang rawan konflik antara golongan, tetapi dapat menjadi pilar dari masyarakat sipil yang berdaya?

\section{Konsep Masyarakat Sipil}

Gabungan kata antara masyarakat dan sipil setidaknya dapat dideskripsikan sebagai suatu perkumpulan individu yang kompleks, tergabung bersama dalam hubungan yang terbentuk oleh kepentingan pribadi, saling ketergantungan ekonomi, aturan hukum, dan peradatan. Dalam perkumpulan seperti ini akan ditemukan orang-orang yang berhubungan satu sama lain untuk persahabatan, untuk mengejar tujuan bersama, untuk bertukar barang dan pikiran. Orang akan mendirikan gereja, klub, universitas, badan usaha, dan berbagai badan dan kegiatan di luar dan dibedakan dari badan yang disebut negara. ${ }^{6}$

Haryatmoko dalam bukunya Etika Politik dan Kekuasaan menempatkan wacana masyarakat sipil (civil society) sebagai bagian dari mekanisme kontrol terhadap kekuasaan. Dengan mengutip teori Antonio Gramsci, ia lebih melihat civil society sebagai arena yang kompleks yang harus dipahami, dimainkan, dan diubah oleh kelas pekerja agar tidak dikuasai oleh kekuatan-kekuatan yang telah memiliki hegemoni secara kodratiah. Dari sini pengertian masyarakat sipil mulai menemukan artinya dalam era globalisasi yaitu peran yang dimainkan oleh lingkungan sipil dalam merebut emansipasi terhadap negara. Pemberdayaan masyarakat sipil dan sektor-sektor sosial mendapat nilai yang setara dengan proyek perubahan struktur-struktur politik.?

Dalam lingkup sosial, sebagai bagian dari struktur sosial, masyarakat sipil dapat dilihat dari dua variable, pertama adalah

${ }^{6}$ Atilla Yayla (ed)., Islam, Masyarakat Sipil dan Ekonomi Pasar, (Jakarta: Stiftung, 2004), h. 53.

${ }^{7}$ Haryatmoko, Etika Politik..., h. 210-211. 
pola struktural atau organisasi institusional yang ditandai oleh kehidupan asosiasi yang kaya dan mengatur diri sendiri, suatu keseimbangan kekuasaan dari sekelompok besar tatanan lain yang berfungsi menyebarkan kekuasaan di luar negara. Variabel kedua adalah cita-cita normatif yang berkaitan dengan kebebasan, harkat individu, hak-hak menentukan diri secara kolektif, dan prosedur regulative untuk interaksi koordinatif antara kelompok-kelompok dan individu-individu dengan cara yang jujur dan demokratis. ${ }^{8}$

\section{Agama dan Cita-Cita Normatif Masyarakat Sipil}

Transformasi agama dalam era modern memang mendapat tantangan keras, terutama karena nilai-nilai modernitas seperti liberalisme dan demokrasi dianggap sebagai produk Barat dan lebih tepat lagi sebagai produk sekularisasi sehingga tidak mempunyai tempat dalam agama. ${ }^{9}$ Muhammad Abid al-Jabiri, seorang pemikir Islam kontemporer asal Maroko, juga melihat dilema yang terjadi di kalangan umat Islam adalah antara mempertahankan tradisi yaitu nilai dan pemikiran yang diwariskan oleh para ulama terdahulu dan mengikuti kemajuan modern yang diasumsikan sebagai nilainilai dan pemikiran barat. ${ }^{10}$

Mencari akar demokrasi dalam Islam atau mempertanyakan apakah demokrasi sesuai dengan Islam merupakan pekerjaan yang melelahkan, selain kurang relevan, karena jelas bahwa tujuan agama sendiri adalah tidak untuk melawan perubahan termasuk kemajuan, apalagi yang mensejahterakan umatnya. Tentu saja harus diakui bahwa sekularisasi yang mencaci maki agama dan menyingkirkan agama seperti candu menjadi catatan sejarah tersendiri bagi umat beragama, namun sejarah itu tidak bisa membentuk sikap traumatik yang membuat umat beragama dalam keterbelakangan. Untuk itu sebuah sikap bijak adalah memikirkan ulang (rethinking) terhadap tradisi yang hendak dipertahankan sehingga agama dan pemeluknya tidak dalam keterasingan

${ }^{8}$ Robert W. Hefner, Islam, Pasar, dan Keadilan; Artikulasi Lokal, Kapitalisme, dan Demokrasi, (Yogyakarta: LKiS, 2000), h. 186.

${ }_{9}$ Atilla Yayla (ed.), Islam, Masyarakat Sipil..., h. 61.

${ }^{10}$ Muhammad Abid al-Jabiri, Post Tradisionalisme Islam, Penerjemah: Ahmad Baso, (Yogyakarta: LKiS, 2000), h. 186. 
dengan perubahan dan modernitas, tetapi justru menjadi subyek dari perubahan.

Kunci utama bagi agama untuk tidak tersingkir dari peradaban modern atau setidaknya tidak menjadikan pemeluknya dalam dilema antara berpegang teguh pada agama dan menerima modernitas adalah kemauan untuk membuka diri. Agama tidak bisa lagi mempertahankan sikap primordialismenya dengan claim-claim kebenarannya sebagai kelompok yang memiliki kebenaran mutlak dan tunggal. Dalam masyarakat sipil seperti telah digambarkan di atas ditandai oleh ruang kepelbagaian, di dalamnya sedikit dengan kesatuan dan lebih banyak dengan pertentangan dan ketidak setujuan, sekalipun pertentangan yang damai. Di dalam masyarakat sipil orang-orang memuja Tuhan yang berbeda-beda dan dengan cara yang berbeda-beda. Tuntutan untuk terbuka, inklusif dan sikap pluralis inilah yang harus di jawab oleh agama di masa kontemporer sekarang ini.

Pluralitas yang perlu dihadirkan oleh agama menurut Haryatmoko tidak cukup hanya atas dasar tuntutan realitas, demi menjaga keteraturan dan keselarasan hidup bersama, demi menjaga kerukunan antara umat beragama. Penerimaan pluralitas itu didasarkan atas pemahaman teologis bahwa "Tuhan menjadi lebih kaya terungkap oleh beragamnya agama dari pada oleh satu tradisi agama saja”. Dengan demikian semua bentuk monopoli kebenaran, sektarianisme tidak mendapat tempat. Dogmatisme yang pada dasarnya merupakan bentuk argument yang cenderung mendasarkan pada otoritas harus didiskusikan secara kritis. Institusi harus dikembalikan pada perannya sebagai sarana mendekatkan kepada Tuhan, jangan justru mengasingkan pemeluknya dari Tuhan dengan membatasi melalui aturan-aturan ketat. ${ }^{11}$

Dengan demikian pluralisme menjadi obat bagi primordialisme yang mensaratkan pemeluk agama untuk tidak hanya menerima dan mengakui kehadiran kelompok dari agama lain tetapi juga kesediaan untuk hidup bersama dalam suatu bangsa. Sebagaimana dinyatakan oleh Bernard Adney Risakota primordialisme mengancam agama sebagai unsur "civil society" karena primordialisme sangat menguatkan solidaritas "in-

${ }^{11}$ Haryatmoko, Etika Politik.., h. 73. 
group"nya (kelompok dalam atau "kami"), dengan memisahkan "kami” dari “out-group"nya (kelompok luar atau "mereka”). ${ }^{12}$

Agar nilai agama bisa menjadi nilai bersama, Kuntowiyo menawarkan konsep obyektivikasi yaitu penerjemahan nilai-nilai internal ke dalam kategori-kategori obyektif. Sesuatu perbuatan disebut obyektif bila perbuatan itu dirasakan oleh orang Islam sebagai sesuatu yang natural (sewajarnya), tidak sebagai perbuatan keagamaan, sekalipun demikian sisi yang mempunyai perbuatan boleh jadi tetap menganggapnya sebagai perbuatan keagamaan, termasuk amal. Obyektifikasi juga dilakukan oleh orang non Islam, asal perbuatan itu dirasakan oleh orang Islam sebagai sesuatu yang obyektif. ${ }^{13}$ Obyektifikasi Islam tetap menganggap al-Qur`an sebagai sumber hukum. Perbedaannya terletak dalam prosedur, tidak dalam hakekat. Obyektifikasi Islam akan menjadikan al-Qur`an terlebih dahulu sebagai hukum positif, yang pembentukannya atas persetujuan bersama warga negara. Dengan demikian tidak langsung seluruh syariat Islam menjadi hukum negara, tetapi melalui obyektifikasi. Proses ini tidak mengabaikan nilai dari agama lain untuk dijadikan hukum negara. Hukum kanonik Kristen kalau akan dijadikan hukum negara harus diobyektifikasi sehingga bisa berlaku untuk semua orang. ${ }^{14}$

Banyaknya kelompok-kelompok dalam masyarakat yang plural khususnya kelompok-kelompok kegamaan menimbulkan pertanyaan bagaimana kemudian obyektifikasi nilai sebagaimana ditawarkan Kuntowijoyo bisa menjadi consensus. Kesulitannya menurut Ulil Abshar Abdalla adalah terkait mengenai idea apa yang disebut masyarakat sesungguhnya, the idea of society, the idea of good society, ide tentang masyarakat yang baik. ${ }^{15}$ Dalam konteks ini sebenarnya bangsa Indonesia pernah memiliki konsensus yang cukup indah yaitu Pancasila. Tetapi kesalahan orde baru dalam memasyarakatkan Pancasila sehingga menjadi mitos, menjadikan

${ }^{12}$ Bernard Adney Risakota, "Civil Society dan Abrahamic Religions", dalam Bernard Adney Risakota, (ed.), Keadilan dan HAM dalam Perspektif Agama-Agama, kumpulan makalah; tidak diterbitkan, h. 65.

${ }^{13}$ Kuntowiyo, Identitas Politk Umat Islam, (Bandung: Mizan, 1997), h. 67.

${ }^{14}$ Ibid. , h. 69.

${ }^{15}$ Ulil Abshar Abdalla, "Civil Society Berbasis Identitas Versus Berbasis Kepentingan”, dalam Burhanudin, Mencari Akar Kultural Civil Society di Indonesia, (Jakarta: INCIS, 2003), h. 80. 
era reformasi ini seolah kehilangan identitas kewarganegaraan yang mengatasi agama, suku, ras dan golongan. Untuk itu Kuntowijoyo juga menyarankan agar Pancasila kembali dilihat sebagai sejarah, yaitu sebagai hasil consensus antar berbagai kelompok dan kepentingan di Indonesia. ${ }^{16}$

Nurcholis Madjid, cendekiawan muslim Indonesia juga melihat Pancasila sebagai hasil usaha para pendiri bangsa dalam meletakkan nilai-nilai asasi kehidupan berbangsa dan bernegara. Pancasila merupakan pijakan bersama dalam usaha membina dan mengembangkan kehidupan bermasyarakat dan bernegara. Menurut Nurcholis, satu hal yang perlu dipertahankan dari Pancasila, adalah kedudukannya sebagai idiologi terbuka. Pandangan sosial politikyang dibentuk oleh Pancasila itu akan absah sepanjang tidak secara kategoris melawan atau menghalangi jiwa dan semangat titik temu kebaikan bersama antara semua golongan, tanpa diskriminasi atau pembedaan satu dari yang lain secara tidak benar. Konsep seperti ini dilandasi oleh paham kemanusiaan universal yang menghendaki agar tiap manusia percaya akan potensi kebaikan tiap-tiap individu. Paham kemanusiaan universal juga percaya kepada adanya kebaikan bersama yang dihasilkan dari dinamika wacana umum dan bebas. ${ }^{17}$

Secara teoritis Pancasila yang dipandang sebagai consensus akan menjadikan anggota masyarakat yang semula tersegmentasi dalam kelompoknya dapat terintegrasi ke dalam berbagai kesatuan sosial (cross cuttin affiliation). Bila hal itu terwujud akan menjadi langkah maju untuk meredam berbagai konflik karena setiap konflikyang terjadi di antara suatu kesatuan sosial dengan kesatuankesatuan sosial yang lain segera akan dinetralisir oleh adanya loyalitas ganda (cross cutting loyalities) dari para anggota masyarakat terhadap berbagai kesatuan sosial. ${ }^{18}$ Namun hal ini tidak otomatis bagi umat Islam misalnya sebagai salah satu unsur dari bangsa Indonesia dapat membangun nilai-nilai bersama dengan unsurunsur sosial yang lain. Pembangunan nilai-nilai bersama tersebut sangat tergantung pada bagaimana nilai-nilai yang telah disepa-

${ }^{16}$ Kuntowiyo, Identitas Politik..., h. 89.

${ }^{17}$ Nurcholish Madjid, Cita-cita Politik Islam Era Reformasi, (Jakarta:Paramadina, 1999), h. 186-187.

${ }^{18}$ Nasikun, Sistem Sosial..., h. 63. 
kati (Pancasila) tersosialisasi secara meluas dalam institusi-institusi sosial atau organisasi masyarakat yang ada.

\section{E. Organisasi Keagamaan Menuju Organisasi Sipil}

Terbentuknya masyarakat sipil tidak hanya tergantung pada adanya nilai-nilai civility, namun juga oranisasi sipil di luar institusi negara dan kekuatan pasar atau kapitalisme. Apakah oraganisasioraganisasi sipil yang ada terutama organisasi keagamaan dapat menjadi oragainisasi sipil yang dapat diandalkan?. Robert W. Hefner, pakar masalah Indonesia dari Boston University melihat pertumbuahan masya-rakat sipil Indonesia dengan penuh optimis. Bahkan dari sisi historis, ia melihat kekuatan masyarakat Islam telah tumbuh sejak abad ke-19, zaman-zaman kerajaan dan penjajahan. Di Indonesia, tutur Hefner, tidak ada hubungan yang menyenangkan antara pemerintah penjajah dengan para pemimpin Muslim. Sebagai gantinya di tempat-tempat seperti Jawa pada abad ke-19, terdapat pertumbuhan yang luar biasa Islam kemasyarakatan. Islam sipil ini pertama kali terorganisir di sekitar institusi kecil yang aneh, yang terkenal sebagai pesantren, sekolah al-Qur`an berasrama. Pesantren-pesantren ini terus memainkan peranan sentral dalam kehidupan keagamaan dan politik Islam tradisionalis hingga hari ini. ${ }^{19}$ Meskipun demikian dalam jangka panjangnya, pesantren tidak bisa berfungsi sebagai dasar bagi pemikiran teori dan praktek politik Islam yang diperbaharui dan demokratis karena struktur kepemimpinannya tetap bersifat kharismatik dan hirarkhis, dan pendekatan kepemimpinannya adalah menggunakan otoritas yang total. ${ }^{20}$

Untuk memenuhi tuntutan agar struktur organisasi seperti pesantren menjadi preseden bagi cita-cita kewargaan, Hefner setidaknya menawarkan dua syarat yang diperlukan, 1) Adanya intelektual yang memiliki tempat berpengaruh yang harus melihat ke dalam pengalaman asosiasi itu dan menjabarkan darinya prinsip-prinsip otonomi, saling menghormati, dan asosiasi bebas yang kemudian bisa digeneralisasikan kepada wilayah public secara keseluruhan. 2) Ia harus diberi kekuatan institusional di dalam kebijakan-kebijakan dan undang-undang negara, juga untuk

\footnotetext{
${ }^{19}$ Hefner, Islam, Pasar..., h. 203.

${ }^{20} \mathrm{Ibid}, \mathrm{h} .206$.
} 
memberikan lingkungan politik yang memperkuat asosiasi-asosiasi sipil dan nilai-nilainya. Syarat kedua ini hendak mengatakan bahwa masyarakat sipil tidak menentang negara tetapi keduanya dapat saling tergantung dan melengkapi. Pada saat yang sama, tidak ada yang alamiah atau niscaya mengenai institusionalisasi nilainilai masyarakat sipil, meskipun prosesnya bisa dipercepat dengan nilai-nilai yang bersaing dan konflik-konflik yang tidak berbudaya (uncivil conflict). ${ }^{21}$

Pada era reformasi sekarang ini di mana Indonesia telah memasuki sejarah baru setelah tumbangnya rezim otoriter, prasyarat yang diajukan Hefner di atas perlu diuji ulang. Apakah hadirnya intelektual berpengaruh di dalam kelompok masingmasing, seperti Abdurrahman Wahid dan kelompok mudanya di NU, Amin Rais, Syafi i Ma`arif dan Din Syamsudin di Muhammadiyah serta kebijakan negara yang sudah lebih demokratis, terbuka dan transparan yang seharusnya menjadi lingkungan yang sehat bagi tumbuhnya masyarakat sipil, sudah berhasil menumbuhkan asosiasi sipil di luar institusi negara dan struktur kapitalis yang berdaya?.

Keraguan akan adanya masyarakat sipil dalam struktur Indonesia pada era reformasi ini akan lebih mengarah pada bentukbentuk partisipasi warga. Hadirnya kelompok intelektual dan iklim demokrasi yang terbuka dan bebas ternyata tidak otomatis melahirkan masyarakat yang memiliki kesadaran sipil, tumbuhnya asosiasi-asosiasi yang memperjuangkan nilai-nilai kewargaan dan keberadaban. Menurut Laode Ida kondisi ini akibat warisan budaya paternalistik, dimana ketergantungan masyarakat terhadap elite kelompoknya yang sangat tinggi. Elite-elite yang meskipun telah memperoleh pendidikan modern dan memiliki wawasan yang luas, namun posisi mereka di hadapan masyarakat masih segalanya (kliental) dalam pengertian tokoh yang memiliki banyak kelebihan dan kemampuan. Celakanya hal ini disadari oleh sang tokoh dan elite politik yang butuh legitimasi masa mengeksploitasinya. Akhirnya basis masa yang dimiliki tokoh masyarakat dijual kepada elite politik. ${ }^{22}$ Perselingkuhan antara elite masyarakat dan agama

${ }^{21}$ Ibid, h. 206-207.

22 Laode Ida, "Kesulitan Membalik Paradigma Elitis Ke Partisipasi Yang Berorientasi Sosial Dalam Pembangunan", dalam Burhanudin, (ed.), Mencari Akar Kultural Civil Society di Indonesia, (Jakarta: INCIS, 2003), h. 152. 
dengan elite politik inilah yang menyebabkan kemandekan tumbuhnya partisipasi warga yang menjadi elemen utama masyarakt sipil.

Hubungan elite dengan masyarakat yang paternalistik saatnya dibongkar menuju masyarakat sipil yang disebut Haryatmoko sebagai sebuah lingkup interaksi sosial antara ekonomi dan negara, yang pertama-tama terdiri dari lingkup intim (khususnya keluarga), lingkup asosiasi (khususnya asosiasi-asosiasi sukarela), gerakan-gerakan sosial (LSM-LSM) dan bentuk-bentuk komunikasi publik lainnya. Masyarakat sipil hanya bisa tumbuh melalui pembentukan diri dan mobilisasi diri atau pemberdayaan diri. Kemudian dilembagakan melalui hukum, dan khususnya melalui hak-hak subyektif. ${ }^{23}$

Dengan demikian organisasi keagamaan seperti NU dan Muhammadiyah yang bersifat identity based dan tidak rasional direvitalisasi menuju yang rasional sebagaimana oraganisasi profesi seperti Persatuan Guru (PGRI), Ikatan Dokter Indonesia (IDI) yang didasarkan pada interest based..$^{24}$ Menjadi bagian dari proses rasionalisasi adalah agenda desentralisasi. Pola kepemimpinan yang sentralistis dan terpusat secara nasional akan menghambat tumbuhnya masyarakat sipil karena mudah terjerumus dalam perjuangan primordial dan identitas kelompok, selain rawan adanya manipulasi terutama berbentuk perselingkuhan dengan kekuasaan politik dan ekonomi. Untuk menjawab hal itu diperlukan penguatan struktur organisasi yang berada di level daerah dengan pemberdayaan diri dan partisipasi warga. Penguatan lebih diarahkan pada tumbuhnya inisiatif dari bawah dan kemauan pada pelembagaan aspirasi-aspirasi tersebut pada tingkat lokal untuk merespon isu-isu yang nampaknya lokal tetapi sangat mempengaruhi tumbuhnya nilai-nilai civility pada masyarakat. Dalam konteks ini, kekuatan organisasi tidak lagi ada dipusat kekuasaan (Jakarta) saja, tetapi justru menyebar di daerah-daerah.

Partisispasi warga dan kekuatan organisasi pada struktur bawah (cabang) di antaranya telah dibuktikan dalam beberapa penelitian mengenai pergumulan agama dan budaya lokal.

${ }^{23}$ Haryatmoko, Etika Politik..., h. 212.

${ }^{24}$ Ulil Abshar Abdalla, "Civil Society”, dalam Burhanudin, Mencari Akar..., h. 80 . 
Dalam disertasi Munir Mulkhan di Wuluhan Jember, mengenai Pemurnian Islam, terbukti bahwa penguatan dan pergeseran elite lokal Muhammadiyah dari ahli syariah yang eksklusif dan mencerminkan fundamentalis Islam murni menuju pemimpin yang toleran terhadab budaya-budaya lokal yang dianggap berbau TBC (tahyyul, bid ah, khurafat) membawa perubahan yang signifikan terhadap hubungan sosial demokratis di Muhammadiyah. Banyak warga dari berbagai latar belakang kultural mendaftarkan diri menjadi anggota Muhammadiyah, tanpa harus meninggalkan tradisi-tradisi yang telah dianutnya, sehingga muncul selain varian Islam murni yang menjadi trade mark Muhammadiyah, juga ada MUNU (Muhammadiyah NU) dan Marmud (MarheinisMuhammadiyah). Perubahan orientasi gerakan juga membuktikan bahwa dakwah Muhammdiyah di Wuluhan tidak berarti Islamisasi tetap pribumisasi. Hal ini dibuktikan dalam aspirasi politik pada masyarakat yang toleran partai-partai yang sekuler seperti Golkar menjadi pilihan warga, padahal di bawah kepemimpinan ulama syariah hal itu tidak pernah terjadi. Dalam level ekonomi, keterbukaan hubungan juga sangat berpengaruh pada peningkatan ekonomi masyarakat petani. ${ }^{25}$

\section{F. Penutup}

Masyarakat sipil dicirikan oleh adanya asosiasi di luar struktur kekuasaan politik dan pasar serta adanya nilai civility atau keberadaban yang berciri demokratis, humanis dan toleran. Segitiga antara masyarakat sipil, politik dan pasar memiliki keberdayaan dan kekuatan yang seimbang untuk menegosiasikan setiap kebijakan-kebijakan sehingga terjaganya nilai-nilai sipil termasuk keselamatan lingkungan.

Agama bisa menjadi penghambat bahkan musuh masyarakat sipil, apabila ia menawarkan nilai-nilai yang eksklusif dan mengedepankan kebenaran yang tunggal. Dalam hal inilah pluralisme menjadi niscaya. Organisasi keagamaan memiliki potensi besar untuk menjadi organisasi sipil dengan syarat adanya transformasi sistem kepemimpinan dari sistem kepemimpinan yang kliental menuju sistem yang lebih demokratis dan lebih banyak

25 Abdul Munir Mulkhan, Islam Murni, Dalam Masyarakat Petani, (Yogyakarta: Bentang, 2000). 
mendorong tumbuhnya partisipasi warga. Managemen organisasi yang terpusat juga perlu direformasi menuju struktur bawah (oraganisasi cabang) yang kuat, yang menyebar di daerah-daerah dan tidak lagi tergantung pada kekuasan politik dan ekonomi. []

\section{Daftar Pustaka}

Abdalla, Ulil Abshar, "Civil Society Berbasis Identitas Versus Berbasis Kepentingan," dalam Burhanudin, Mencari AkarKultural Civil Society di Indonesia, Jakarta: INCIS, 2003

al-Jabiri, Muhammad Abid, Post Tradisionalisme Islam, Penerjemah: Ahmad Baso, Yogyakarta: LKiS, 2000

Giddens, Anthony, The Third Way And Its Critics, Penerjemah: Imam Khoiri, Yogyakarta: IRCiSoD, 2000

Haryatmoko, Etika Politik dan Kekuasaan, Jakarta: Penerbit Buku Kompas, 2003

Hefner, Robert W., Islam, Pasar, dan Keadilan; Artikulasi Lokal, Kapitalisme, dan Demokrasi,Yogyakarta: LKiS, 2000

Ida, Laode, Kesulitan Membalik Paradigma Elitis Ke Partisipasi Yang Berorientasi Sosial Dalam Pembangunan, dalam Burhanudin, ed., Mencari Akar Kultural Civil Society di Indonesia, Jakarta: INCIS, 2003

Kuntowiyo, Identitas Politk Umat Islam, Bandung: Mizan, 1997

Mulkhan, Abdul Munir, Islam Murni, Dalam Masyarakat Petani, Yogyakarta: Bentang, 2000

Risakota, Bernard Adney, Civil Society dan Abrahamic Religions, dalam Bernard Adney Risakota,ed., Keadilan dan HAM dalam Perspektif Agama-Agama, kumpulan makalah; tidak diterbitkan,

Wahono, Francis, Bersekongkol atau Saling Kontrol, dalam Duto Sosialismanto, Hegemoni Negara, Ekonomi, Politik Pedesaan Jawa, Yogyakarta: Lapera Pustaka Utama, 2000

Yayla, Atilla (ed.), Islam, Masyarakat Sipil dan Ekonomi Pasar, Jakarta: Stiftung, 2004. 